\title{
Behavior of Five Sulfonylurea Herbicides and a Low-Dose Glyphosate on Cynodon nlemfuensis Pasture
}

\author{
Alexandre M. Brighenti ${ }^{1}$, Flávio R. G. Benites ${ }^{1}$, Fausto Souza Sobrinho ${ }^{1}$, Carlos E. Martins ${ }^{1}$ \\ \& Wadson S. D. Rocha ${ }^{1}$ \\ ${ }^{1}$ Embrapa Dairy Cattle, Juiz de Fora, Minas Gerais State, Brazil \\ Correspondence: Alexandre M. Brighenti, Embrapa Dairy Cattle, Rua Eugênio do Nascimento, n. 610, B. Dom \\ Bosco, Juiz de Fora, Minas Gerais State, Brazil. Tel: 55-032-3311-7556. E-mail: \\ alexandre.brighenti@embrapa.br
}

Received: November 12, 2018 Accepted: February 3, $2019 \quad$ Online Published: January 15, 2020

doi:10.5539/jas.v12n2p160

URL: https://doi.org/10.5539/jas.v12n2p160

The research is financed by FAPEMIG and CNPq.

\begin{abstract}
African star grass (Cynodon nlemfuensis Vanderyst) is an excellent forage for animal feed, especially in tropical and subtropical climates. However, there is little information on weed management in African star grass pastures. Two experiments were carried out in 2017 and 2018 to evaluate the response of African star grass to five herbicides of the sulfonylureas chemical group and glyphosate at a low dose. The treatments were as follows: metsulfuron-methyl (Ally $\left.{ }^{\circledR}\right)\left(7.8\right.$ and $15.6 \mathrm{~g}$ ai ha ${ }^{-1}$ plus $0.1 \% \mathrm{v} / \mathrm{v}$ mineral oil); chlorimuron-ethyl

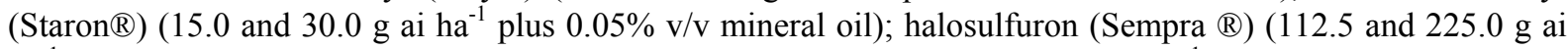
$\mathrm{ha}^{-1}$ plus $0.1 \% \mathrm{v} / \mathrm{v}$ surfactant); ethoxysulfuron (Gladium $\left.{ }^{\circledR}\right)\left(150.0\right.$ and $300.0 \mathrm{~g}^{2}$ ai $^{-1}$ ); nicosulfuron (Sanson $\left.{ }^{\circledR}\right)$ (60.0 and $120.0 \mathrm{~g}$ ai ha $\left.{ }^{-1}\right)$; glyphosate (Roundup Original $\left.{ }^{\circledR}\right)\left(360 \mathrm{~g} \mathrm{ae} \mathrm{ha}^{-1}\right)$; and a control without herbicide application. The herbicides nicosulfuron $\left(60.0\right.$ and $120.0 \mathrm{~g}$ ai ha $\left.^{-1}\right)$ and glyphosate were the most phytotoxic treatments; however, none of the treatments caused the total death of African star grass plants. The herbicides metsulfuron-methyl, chlorimuron-ethyl, halosulfuron and ethoxysulfuron were selective and are potential products for use in African star grass pastures.
\end{abstract}

Keywords: chemical control, forages, tolerance, weeds

\section{Introduction}

Species of the genus Cynodon exhibit high productive potential and nutritional value. Many genotypes are widespread throughout the world, especially in tropical and subtropical cultivation conditions (Athayde et al., 2005). Some genetically improved cultivars have been obtained in the United States (Seghese, 2009). Among the most promising are Florona and Florico, with are associated with the production of high-quality forage and resistance to pests, diseases and low temperatures (Mislevy et al., 1989a, 1989b).

One widely cultivated species is African star grass (Cynodon nlemfuensis Vanderyst), which is used as an alternative for feeding herds and forming new pastures (Pedreira, 2010). The species is perennial, stoloniferous, without rhizomes, forming a canopy of 0.30 to $0.70 \mathrm{~m}$ in height, wide-leafed and, often arched, and has, racemes of 4 to $10 \mathrm{~cm}$ and pale green to purple coloration (Athayde et al., 2005). African star grass is propagated by stolons, since its seeds have low fertility. This species presents good development in regions with rainfall indices of over $800 \mathrm{~mm} /$ year (Sollenberger, 2008). African star grass plants tolerate short periods of flooding (3 to 5 days) with a water depth of 2 to $5 \mathrm{~cm}$ (Vendramini \& Mislevy, 2016). In addition, this species is resistant to drought; however, the plants do not develop satisfactorily in shaded areas (Andrade et al., 2009).

African star grass in rotational grazing conditions, with a 30-day interval, plus a supplement of $2 \mathrm{~kg}$ per cow per day of concentrate, provide the nutritional energy for maintaining and producing $11.7 \mathrm{~kg}$ of milk per cow per day (Favoreto et al., 2008). Plants can be stored satisfactorily as silage (Evangelista et al., 2000). The process of ensiling is done soon after cutting or after the plants are subjected up to $3 \mathrm{~h}$ of wilting.

Although African star grass is considered a forage crop, some barriers to planting and crop conduction need to be elucidate. The results of chemical weed control in African star grass and the response of this species to 
herbicides are scarce. In addition, there are no registered products for weed control in African star grass pastures in Brazil (MAPA, 2018).

Thus, studies that elucidate the tolerance of African star grass to herbicides are essential to avoid toxic damage to plants and prevent from weed interference.

The present study aims to evaluate the response of African star grass to five sulfonylureas herbicides and to glyphosate at a low dose.

\section{Method}

\subsection{Study Sites}

Two experiments were conducted in the municipality of Coronel Pacheco, Minas Gerais State, Brazil $\left(21^{\circ} 32^{\prime} 51.96^{\prime \prime} \mathrm{S}\right.$ and $\left.43^{\circ} 15^{\prime} 40.04^{\prime \prime} \mathrm{W}\right)$, in 2017 and 2018.

\subsection{Treatments and Experimental Design}

Sulfonylureas herbicides were applied using the doses normally recommended for cultivation, described on the herbicide labels (X), as well as double doses (2X) (MAPA, 2018). Glyphosate was applied at a low dose in order to avoid severe injury to forage plants. The experiments were arranged in randomized complete block design with four replications. The treatments were as follows: metsulfuron-methyl (Ally $\left.{ }^{\circledR}\right)\left(7.8\right.$ and $15.6 \mathrm{~g}$ ai ha ${ }^{-1}$ plus $0.1 \%$ $\mathrm{v} / \mathrm{v}$ mineral oil); chlorimuron-ethyl (Staron $\left.{ }^{\circledR}\right)\left(15.0\right.$ and $30.0 \mathrm{~g}$ ai ha ${ }^{-1}$ plus $0.05 \% \mathrm{v} / \mathrm{v}$ mineral oil); halosulfuron (Sempra $\left.{ }^{\circledR}\right)\left(112.5\right.$ and $225.0 \mathrm{~g}$ ai ha ${ }^{-1}$ plus $0.1 \% \mathrm{v} / \mathrm{v}$ surfactant); ethoxysulfuron (Gladium $\left.{ }^{\circledR}\right)(150.0$ and $300.0 \mathrm{~g}$

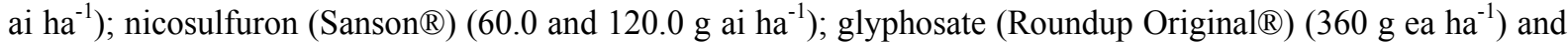
a control without herbicide application.

\subsection{Experimental Implantations and Climate Conditions}

The soil of the experimental area is classified as Fluvic Cambisol which has a chemical composition $(0-20 \mathrm{~cm}$ depth) as follows: $\mathrm{pH}\left(\mathrm{H}_{2} \mathrm{O}\right)=5.8, \mathrm{P}=79.4 \mathrm{mg} \mathrm{dm}{ }^{-3}, \mathrm{~K}=370 \mathrm{mg} \mathrm{dm}^{-3}, \mathrm{Ca}^{2+}=3.92 \mathrm{cmolc} \mathrm{dm}^{-3}, \mathrm{Mg}^{2+}=1.5$ $\mathrm{cmolc} \mathrm{dm}^{-3}, \mathrm{Al}^{3+}=0.0 \mathrm{cmolc} \mathrm{dm}^{-3}, \mathrm{H}+\mathrm{Al}=5.2 \mathrm{cmolc} \mathrm{dm}^{-3}, \mathrm{CTC}(\mathrm{T})=11.7 \mathrm{cmolc} \mathrm{dm}^{-3}$ and $\mathrm{V}=55 \%$. The experimental areas were in established grassland, entirely covered with African star grass. The weeds present in the area were eliminated manually, leaving only the forage plants. The experimental plots covered an area of 15 $\mathrm{m}^{2}(3 \times 5 \mathrm{~m})$. The aerial part of the plants was cut one month before herbicide application in order to standardize the plant stand and avoid overgrowth of the forage.The treatments were applied on November 11, 2017 (experiment 1) and on April 9, 2018 (experiment 2) when the African star grass plant height was approximately $0.30 \mathrm{~m}$. A backpack sprayer at constant $\mathrm{CO}_{2}$ pressure $\left(2 \mathrm{kgf} \mathrm{cm}^{-2}\right)$ was used to deliver a volume of $150 \mathrm{~L} \mathrm{ha}^{-1}$. The spray boom was composed of four flat fan nozzles 110.02 (Magno ADGA), spaced $0.5 \mathrm{~m}$ apart. The climatic conditions during the application of the treatments were as follows: experiment 1 (temperature $25{ }^{\circ} \mathrm{C}$, relative humidity $80 \%$ and wind speed $2.5 \mathrm{~m} \mathrm{~s}^{-1}$ ) and experiment 2 (temperature $22{ }^{\circ} \mathrm{C}$, relative humidity $75 \%$ and wind speed $\left.2.0 \mathrm{~m} \mathrm{~s}^{-1}\right)$.

The temperatures (maximum and minimum average) and rainfall during the experimental periods are shown in Table 1.

Table 1. Average maximum and minimum monthly air temperatures (T) and rainfall during the experimental periods. Coronel Pacheco, Minas Gerais State, Brazil

\begin{tabular}{lllllc}
\hline Sites & \multicolumn{3}{c}{ Experiment 1} & & \multicolumn{2}{c}{ Experiment 2} \\
\cline { 1 - 2 } \cline { 5 - 6 } Month/Year & Nov/17 & Dec/17 & & Apr/18 & May/18 \\
\cline { 1 - 4 } Maximum T $\left({ }^{\circ} \mathrm{C}\right)$ & 25.5 & 27.0 & & 24.6 & 22.5 \\
Minimum T $\left({ }^{\circ} \mathrm{C}\right)$ & 24.3 & 25.7 & & 22.5 & 21.0 \\
Rainfall $(\mathrm{mm})$ & 160.6 & 147.4 & & 111.0 & 42.0 \\
\hline
\end{tabular}

\subsection{Sampling and Measurements}

The percentage of herbicide phytotoxicity on African star grass plants was evaluated at 7, 14, 21 and 28 days after application of the treatments (DAA). A $0-100 \%$ scale was used, where zero corresponded to no symptoms of phytotoxicity on African star grass plants and $100 \%$ corresponded to total death of the plants (SBCPD 2005). SPAD (Soil Plant Analysis Development) indices were determined at 14 DAA using a SPAD 502 portable chlorophyllometer from Konica Minolta, Japan. Plant height was determined at 23 and 35 DAA using a graduated ruler. Fresh matter from the aerial part of African star grass plants was collected within the net area of 
each plot at 35 DAA, simulating the recommended rest period for Cynodon species of 3-5 weeks, in which it is possible to obtain highly digestible and crude protein forage (Fontaneli et al., 2012). The plants were cut on the soil surface within a quadrat $\left(0.5 \times 0.5 \mathrm{~m}-0.25 \mathrm{~m}^{2}\right)$. The samples were packed in paper bags and placed in a forced-air ventilation oven at $65^{\circ} \mathrm{C}$ for $72 \mathrm{~h}$. The dry matter weight was obtained by weighing the samples on a scale and the data were converted to $\mathrm{kg} \mathrm{ha}^{-1}$.

\subsection{Statistical Analysis}

Percent phytotoxicity values were normalized by square root transformation of $(x+1)$ in order to perform analysis of variance (ANOVA) tests. Data were submitted to ANOVA, and means were compared by the Scott-Knott test $(P \leq 0.05)$. Statistical analyses were performed using SAEG (Statistical and Genetic Analysis System) software (Ribeiro Júnior 2001).

\section{Results and Discussion}

The phytotoxicity percentages of the herbicides on African star grass plants for experiments 1 and 2 are shown in Tables 2 and 3, respectively.

Table 2. Percentage of phytotoxicity at 7 (P7), 14 (P14), 21 (P21) and 28 (P28) days after application of treatments. Coronel Pacheco, Minas Gerais State, Brazil, 2017. Experiment 1

\begin{tabular}{llllll}
\hline Treatments & Doses $\left(\mathrm{g} \mathrm{ha}^{-1}\right)$ & P7 & P14 & P21 & P28 \\
\hline Metsulfuron & 7.8 & $0.0 \mathrm{D}^{1}$ & $0.0 \mathrm{D}$ & $0.0 \mathrm{D}$ & $0.0 \mathrm{D}$ \\
& 15.6 & $0.0 \mathrm{D}$ & $0.0 \mathrm{D}$ & $0.0 \mathrm{D}$ & $0.0 \mathrm{D}$ \\
Chlorimuron & 15.0 & $0.0 \mathrm{D}$ & $0.0 \mathrm{D}$ & $0.0 \mathrm{D}$ & $0.0 \mathrm{D}$ \\
& 30.0 & $0.0 \mathrm{D}$ & $0.0 \mathrm{D}$ & $0.0 \mathrm{D}$ & $0.0 \mathrm{D}$ \\
\hline Halosulfuron & 112.5 & $0.0 \mathrm{D}$ & $0.0 \mathrm{D}$ & $0.0 \mathrm{D}$ & $0.0 \mathrm{D}$ \\
& 225.0 & $0.0 \mathrm{D}$ & $0.0 \mathrm{D}$ & $0.0 \mathrm{D}$ & $0.0 \mathrm{D}$ \\
Ethoxysulfuron & 150.0 & $0.0 \mathrm{D}$ & $0.0 \mathrm{D}$ & $0.0 \mathrm{D}$ & $0.0 \mathrm{D}$ \\
& 300.0 & $0.0 \mathrm{D}$ & $0.0 \mathrm{D}$ & $0.0 \mathrm{D}$ & $0.0 \mathrm{D}$ \\
Nicosulfuron & 60.0 & $17.0 \mathrm{C}$ & $12.2 \mathrm{C}$ & $10.0 \mathrm{C}$ & $8.7 \mathrm{C}$ \\
\hline Glyphosate & 120.0 & $23.0 \mathrm{~B}$ & $15.7 \mathrm{~B}$ & $13.5 \mathrm{~B}$ & $12.5 \mathrm{~B}$ \\
\hline Control & 360.0 & $25.5 \mathrm{~A}$ & $20.2 \mathrm{~A}$ & $16.5 \mathrm{~A}$ & $15.0 \mathrm{~A}$ \\
\hline Coefficient of Variation & - & $0.0 \mathrm{D}$ & $0.0 \mathrm{D}$ & $0.0 \mathrm{D}$ & $0.0 \mathrm{D}$ \\
\hline
\end{tabular}

Note. ${ }^{1}$ Mean values followed by different letters are significantly $(P \leq 0.05)$ different by Scott-Knott test.

Table 3. Percentage of phytotoxicity at 7 (P7), 14 (P14), 21 (P21) and 28 (P28) days after application of treatments. Coronel Pacheco, Minas Gerais State, Brazil, 2018. Experiment 2

\begin{tabular}{llllll}
\hline Treatments & Doses $\left(\mathrm{g} \mathrm{ha}^{-1}\right)$ & $\mathrm{P} 7$ & $\mathrm{P} 14$ & $\mathrm{P} 21$ & $\mathrm{P} 28$ \\
\hline Metsulfuron & 7.8 & $2.5 \mathrm{D}^{1}$ & $0.0 \mathrm{D}$ & $0.0 \mathrm{D}$ & $0.0 \mathrm{D}$ \\
\hline Chlorimuron & 15.6 & $2.5 \mathrm{D}$ & $0.0 \mathrm{D}$ & $0.0 \mathrm{D}$ & $0.0 \mathrm{D}$ \\
\hline Halosulfuron & 15.0 & $0.0 \mathrm{E}$ & $0.0 \mathrm{D}$ & $0.0 \mathrm{D}$ & $0.0 \mathrm{D}$ \\
& 30.0 & $0.0 \mathrm{E}$ & $0.0 \mathrm{D}$ & $0.0 \mathrm{D}$ & $0.0 \mathrm{D}$ \\
Ethoxysulfuron & 112.5 & $0.0 \mathrm{E}$ & $0.0 \mathrm{D}$ & $0.0 \mathrm{D}$ & $0.0 \mathrm{D}$ \\
& 225.0 & $0.0 \mathrm{E}$ & $0.0 \mathrm{D}$ & $0.0 \mathrm{D}$ & $0.0 \mathrm{D}$ \\
Nicosulfuron & 150.0 & $0.0 \mathrm{E}$ & $0.0 \mathrm{D}$ & $0.0 \mathrm{D}$ & $0.0 \mathrm{D}$ \\
$-{ }^{\prime}$ & 300.0 & $0.0 \mathrm{E}$ & $0.0 \mathrm{D}$ & $0.0 \mathrm{D}$ & $0.0 \mathrm{D}$ \\
\hline Glyphosate & 60.0 & $15.5 \mathrm{C}$ & $22.0 \mathrm{C}$ & $17.7 \mathrm{C}$ & $4.7 \mathrm{C}$ \\
\hline Control & 120.0 & $21.0 \mathrm{~B}$ & $26.0 \mathrm{~B}$ & $21.0 \mathrm{~B}$ & $7.5 \mathrm{~B}$ \\
\hline
\end{tabular}

Note. ${ }^{1}$ Mean values followed by different letters are significantly $(P \leq 0.05)$ different by Scott-Knott test.

Treatments with metsulfuron-methyl, chlorimuron-ethyl, halosulfuron and ethoxysulfuron at $\mathrm{X}$ and $2 \mathrm{X}$ caused no phytotoxic symptoms at any evaluation, except for the two metsulfuron-methyl doses at the first evaluation 
(experiment 2) (Table 3). Although metsulfuron caused leaf chlorosis at the first evaluation, values were low $(2.5 \%)$ and disappeared at 14 DAA. Janak et al. (2015) verified that the application of metsulfuron methyl (0.02 $\mathrm{kg} \mathrm{h}^{-1}$ ) on Tifton 85 Bermudagrass (Cynodon dactylon) exhibited little chlorosis and no necrosis, growth or yield reduction at any time. The herbicides halosulfuron $\left(112.5 \mathrm{~g}\right.$ ai ha $\left.{ }^{-1}\right)$, metsulfuron-methyl $\left(2.4 \mathrm{~g}\right.$ ai ha $\left.{ }^{-1}\right)$, chlorimuron-ethyl $\left(15 \mathrm{~g}_{\text {ai ha}}{ }^{-1}\right)$ were previously applied on Bermuda grass plants (Tifton 419-C. dactylon $\times$ C. transvaalensis) (Dias, 2018). None of the herbicides caused injury to the plants, and the herbicides were considered selective to Tifton 419. Halosulfuron methyl $75 \% \mathrm{WG}$ at $3.3 \mathrm{~g} / 10 \mathrm{~L}$ was applied on Bermuda grass (Cynodon spp.) (Desai et al., 2017). The herbicide provided efficient control of purple nutsedge (Cyperus rotundus L.) and caused no phytotoxic symptoms on Bermuda grass plants. According to Christoffoletti and Aranda (2001), halosulfuron (112.5 $\left.\mathrm{g}_{\text {ai ha}}{ }^{-1}\right)$ caused slight symptoms when applied on Bermudagrass plants $(C$. dactylon), with a total recovery of the plants at 50 DAA. Single application of halosulfuron $\left(70 \mathrm{~g}^{\mathrm{ai}} \mathrm{ha}^{-1}\right)$ controlled yellow nutsedge (Cyperus esculentus) greater than $80 \%$ when nutsedge was in Bermuda grass (Cynodon dactylon) fields (Blum et al., 2000).

Among the herbicides that belong to the chemical group of sulfonylureas, nicosulfuron was the most phytotoxic. The percentages of phytotoxicity reached values ranging from $15.5 \%$ to $23 \%$ at the first evaluation for both experiments. The characteristic symptoms were the chlorosis on younger leaves that persisted up to 21 DAA. Symptoms were still visible in the last phytotoxic evaluation, even with plant recovery. Regarding corn tolerance to nicosulfuron, phytotoxic symptoms caused by a dose of $40 \mathrm{~g}$ ai ha ${ }^{-1}$ were observed by Môro and Damião Filho (1999). The intensity of symptoms was genotype dependent, and symptoms were intense mainly 7 to 14 days after application. The characteristics of injury were chlorosis and wrinkling of the blades of the expanding central leaves. Nicosulfuron was previously applied at $40 \mathrm{~g}$ ai ha ${ }^{-1}$ on African star grass pasture to control Brachiaria (Alves et al., 2012). Brachiaria control was effective; however, nicosulfuron was highly phytotoxic to African star grass.

Glyphosate was the most phytotoxic treatment. The percentage of injury was $25.5 \%$ at 7 DAA (experiment 1 ) (Table 2). The characteristic symptoms were yellowing of the leaf blades, and necrosis of the tips of the leaves. The plants were observed to recover from the second evaluation until 28 DAA (15\%). The symptoms were more pronounced in experiment 2 and reached values of $69 \%$ at 21 DAA (Table 3). Plant recovery reached $21 \%$ at 28 DAA. Plant recovery in the glyphosate treatment was faster in experiment 1 than in experiment 2 . This fact may be related to the season during which the experiments were conducted. Temperatures and rainfall conditions were higher during experiment 1 (Table 1), which probably favored the faster recovery of plants. Tifton 85 (Cynodon spp.) also tends to show greater tolerance to glyphosate in the summer (Santos et al., 2010) which is probably due to favorable conditions for growth and development, such as temperature, which may be related to the ease of metabolism, conjugation and/or exudation of the herbicide by the plants.

SPAD indices, plant heights and dry matter weights are shown in Tables 4 and 5 for experiments 1 and 2, respectively.

Table 4. SPAD indices at 23 days after application of the treatments (DAA), plant heights (cm) at 23 DAA (H1) and 35 DAA (H2), and dry matter weight (DMW) $\left(\mathrm{kg} \mathrm{ha}^{-1}\right)$. Coronel Pacheco, Minas Gerais State, Brazil, 2017. Experiment 1

\begin{tabular}{|c|c|c|c|c|c|}
\hline Treatments & Doses $\left(\mathrm{g} \mathrm{ha}^{-1}\right)$ & SPAD & H1 & $\mathrm{H} 2$ & DMW \\
\hline \multirow{2}{*}{ Metsulfuron } & 7.8 & $32.5 \mathrm{~A}^{1}$ & $70.9 \mathrm{~B}$ & $81.2 \mathrm{~A}$ & $5,096.9 \mathrm{~A}$ \\
\hline & 15.6 & $31.0 \mathrm{~A}$ & $71.1 \mathrm{~B}$ & $82.0 \mathrm{~A}$ & $4,559.5 \mathrm{~A}$ \\
\hline \multirow{2}{*}{ Chlorimuron } & 15.0 & $29.5 \mathrm{~A}$ & $71.7 \mathrm{~A}$ & $82.0 \mathrm{~A}$ & $5,166.1 \mathrm{~A}$ \\
\hline & 30.0 & $29.3 \mathrm{~A}$ & $70.8 \mathrm{~B}$ & $81.7 \mathrm{~A}$ & $5,246.7 \mathrm{~A}$ \\
\hline \multirow{2}{*}{ Halosulfuron } & 112.5 & $29.7 \mathrm{~A}$ & $71.0 \mathrm{~B}$ & $82.7 \mathrm{~A}$ & $5,399.9 \mathrm{~A}$ \\
\hline & 225.0 & $31.0 \mathrm{~A}$ & $72.3 \mathrm{~A}$ & $82.2 \mathrm{~A}$ & $4,784.2 \mathrm{~A}$ \\
\hline \multirow{2}{*}{ Ethoxysulfuron } & 150.0 & $30.7 \mathrm{~A}$ & $71.8 \mathrm{~A}$ & $82.7 \mathrm{~A}$ & $4,945.1 \mathrm{~A}$ \\
\hline & 300.0 & $29.8 \mathrm{~A}$ & $71.7 \mathrm{~A}$ & $82.7 \mathrm{~A}$ & $5,186.6 \mathrm{~A}$ \\
\hline \multirow{2}{*}{ Nicosulfuron } & 60.0 & $17.0 \mathrm{~B}$ & $29.2 \mathrm{C}$ & $50.5 \mathrm{~B}$ & $4,022.4 \mathrm{~B}$ \\
\hline & 120.0 & $14.7 \mathrm{C}$ & $20.6 \mathrm{D}$ & $43.0 \mathrm{C}$ & $4,152.8 \mathrm{~B}$ \\
\hline Glyphosate & 360.0 & $12.0 \mathrm{D}$ & $17.1 \mathrm{E}$ & $38.2 \mathrm{D}$ & $3,185.7 \mathrm{~B}$ \\
\hline Control & - & $31.2 \mathrm{~A}$ & $70.7 \mathrm{~B}$ & $83.5 \mathrm{~A}$ & $5,978.8 \mathrm{~A}$ \\
\hline Coefficient of Variation & - & 5.7 & 1.1 & 1.9 & 13.3 \\
\hline
\end{tabular}

Note. ${ }^{1}$ Mean values followed by different letters are significantly $(P \leq 0.05)$ different by Scott-Knott test. 
Table 5. SPAD indices at 14 days after application of the treatments (DAA), plant heights (cm) at 23 DAA (H1) and 35 DAA (H2), and dry matter weight (DMW) $\left(\mathrm{kg} \mathrm{ha}^{-1}\right)$. Coronel Pacheco, Minas Gerais State, Brazil, 2018. Experiment 2

\begin{tabular}{|c|c|c|c|c|c|}
\hline Treatments & Doses $\left(\mathrm{g} \mathrm{ha}^{-1}\right)$ & SPAD & $\mathrm{H} 1$ & $\mathrm{H} 2$ & DMW \\
\hline \multirow{2}{*}{ Metsulfuron } & 7.8 & $18.0 \mathrm{~B}^{1}$ & $55.5 \mathrm{~B}$ & $85.0 \mathrm{~A}$ & $9,682.7 \mathrm{~A}$ \\
\hline & 15.6 & $17.3 \mathrm{~B}$ & $55.5 \mathrm{~B}$ & $85.5 \mathrm{~A}$ & $11,563.8 \mathrm{~A}$ \\
\hline \multirow{2}{*}{ Chlorimuron } & 15.0 & $21.7 \mathrm{~A}$ & $55.7 \mathrm{~B}$ & $85.0 \mathrm{~A}$ & $11,771.3 \mathrm{~A}$ \\
\hline & 30.0 & $21.1 \mathrm{~A}$ & $63.7 \mathrm{~A}$ & $84.0 \mathrm{~A}$ & $11,652.5 \mathrm{~A}$ \\
\hline \multirow{2}{*}{ Halosulfuron } & 112.5 & $22.0 \mathrm{~A}$ & $65.0 \mathrm{~A}$ & $85.7 \mathrm{~A}$ & $12,142.3 \mathrm{~A}$ \\
\hline & 225.0 & $21.5 \mathrm{~A}$ & $63.5 \mathrm{~A}$ & $85.2 \mathrm{~A}$ & $11,805.6 \mathrm{~A}$ \\
\hline \multirow{2}{*}{ Ethoxysulfuron } & 150.0 & $21.1 \mathrm{~A}$ & $64.2 \mathrm{~A}$ & $85.7 \mathrm{~A}$ & $11,665.6 \mathrm{~A}$ \\
\hline & 300.0 & $21.8 \mathrm{~A}$ & $64.0 \mathrm{~A}$ & $85.2 \mathrm{~A}$ & $12,630.8 \mathrm{~A}$ \\
\hline \multirow{2}{*}{ Nicosulfuron } & 60.0 & $15.6 \mathrm{C}$ & $30.5 \mathrm{C}$ & $51.5 \mathrm{~B}$ & $6,769.0 \mathrm{~B}$ \\
\hline & 120.0 & $14.5 \mathrm{C}$ & $30.2 \mathrm{C}$ & $50.2 \mathrm{~B}$ & $7,136.8 \mathrm{~B}$ \\
\hline Glyphosate & 360.0 & $11.3 \mathrm{D}$ & $30.7 \mathrm{C}$ & $37.7 \mathrm{C}$ & $5,172.9 \mathrm{~B}$ \\
\hline Control & - & $22.6 \mathrm{~A}$ & $63.0 \mathrm{~A}$ & $86.0 \mathrm{~A}$ & $13,541.9 \mathrm{~A}$ \\
\hline Coefficient of Variation & - & 6.1 & 2.4 & 1.8 & 14.7 \\
\hline
\end{tabular}

Note. ${ }^{1}$ Mean values followed by different letters are significantly $(P \leq 0.05)$ different by Scott-Knott test.

SPAD indices did not differ statistically from those of the control, except for the herbicides nicosulfuron and glyphosate (experiment 1) (Table 4). The results were similar in experiment 2. However, in addition to nicosulfuron and glyphosate, metsulfuron-methyl also caused a reduction in SPAD indices (Table 5). This fact confirms the initial visible symptoms caused by metsulfuron-methyl on African star grass plants $(2.5 \%)($ Table 3).

No treatments caused a reduction in African star grass plant height at 35 DAA and dry matter yield, except for nicosulfuron and glyphosate (Tables 3 and 5).

Both nicosulfuron and glyphosate caused phytotoxic effects on African star grass plants by reducing plant size and dry matter production. However, there was no total plant death. This observation was also verified in Tifton 85 which showed tolerance to glyphosate at $720 \mathrm{~g} \mathrm{ha}^{-1}$ (Santos et al., 2007, 2008). This same behavior was also previously observed in African star grass pasture (Brighenti et al., 2012, 2013). Lower doses of glyphosate were tolerated by African star grass that had been established over 8 years; thus, such application is a viable tool for chemical weed control in African star grass pastures.

\section{Conclusions}

The herbicides nicosulfuron (60 and $\left.120 \mathrm{~g} \mathrm{ha}^{-1}\right)$ and glyphosate $\left(360 \mathrm{~g} \mathrm{ha}^{-1}\right)$ were the most phytotoxic treatments; however, no total death was observed in the African star grass plants. The herbicides metsulfuron-methyl, chlorimuron-ethyl, halosulfuron and ethoxysulfuron were selective and, are thus potential products for use in African star grass pastures.

\section{Acknowledgements}

The financial support from Fundação de Amparo a Pesquisa do Estado de Minas Gerais (FAPEMIG) and the Conselho Nacional de Desenvolvimento Científico e Tecnológico (CNPq) is highly appreciated.

\section{References}

Alves, S. J., Alves, R. M. L., \& Soler, J. A. (2012). Avaliação de herbicidas para o estabelecimento de grama estrela por mudas com raiz em pastagem degradada de braquiária. Ambiência-Revista do Setor de Ciência Agrárias e Ambientais, 8(3), 895-900. https://doi.org/10.5777/ambiencia.2012.05.08

Andrade, C. M. S., Assis, G. M. L., Fazolin, M., Gonçalves, R. C., Sales, M. F. L., Valentim, J. F., \& Estrela, J. L. V. (2009). Grama-estrela-roxa: Gramínea forrageira para diversificação de pastagem no Acre (p. 83). Rio Branco, AC. Embrapa Acre.

Athayde, A. A. R., Carvalho, R. C. R, Medeiros, L. T., Valeriano, A. R., \& Rocha, G. P. (2005). Gramíneas do gênero Cynodon-Cultivares recentes no Brasil (Boletim Técnico 73, pp. 1-14). Lavras: Universidade Federal de Lavras. 
Blum, R. R., Isgrigg, J., \& Yelverton, F. H. (2000). Purple (Cyperus rotundus) and yellow nutsedge (C. esculentus) control in bermudagrass (Cynodon dactylon) turf. Weed Technology, 14(2), 357-365. https://doi.org/10.1614/0890-037X(2000)014[0357:PCRAYN]2.0.CO;2

Brighenti, A. M., \& Vieira, P. H. S. (2013). Recovery of Cynodon nlemfuensis pasture after desiccation with glyphosate in pre-sowing of maize. Applied Research \& Agrotecnology, 6(2), 57-64. https://doi.org/10.5935/ PAeT.V6.N2.06

Brighenti, A. M., Martins, C. E., Souza Sobrinho, F., Rocha, W. S. D., Calsavara, L. H. F., \& Nicodemos, L.C. (2012). Capacidade de restabelecimento da grama-estrela-africana após aplicação de glifosato em pré-semeadura de milho. Pesquisa Agropecuária Brasileira, 47(10), 43-1448. https://doi.org/10.1590/ S0100-204X2012001000005

Christoffoleti, P. J., \& Aranda, A. N. (2001). Seletividade de herbicidas a cinco tipos de gramas. Planta Daninha, 19(2), 273-278. https://doi.org/10.1590/S0100-83582001000200016

Desai, M., Patel, G. D., Patel, N. K., Bhatt, S. T., \& Patel, M. (2017). Effect of different herbicides on Cyperus rotundus L. in turf. Journal of Pharmacognosy and Phytochemistry, 6(6), 643-647. Retrieved from http://www.phytojournal.com/archives/2017/vol6issue6/PartJ/6-6-35-351.pdf

Dias, R. C. (2018). Seletividade de herbicidas aplicados em pós-emergência em espécies de grama (p. 92, Tese Mestrado, Universidade Estadual Paulista, Botucatu-SP).

Evangelista, A. R., Lima, J. A., \& Bernardes, T. F. (2000). Avaliação de algumas características da silagem de gramínea estrela-roxa (Cynodon nlemfuensis Vanderyst). Revista Brasileira de Zootecnia, 29(4), 941-946. https://doi.org/10.1590/S1516-35982000000400001

Favoreto, M. G., Deresz, F., Fernandes, A. M., Vieira, R. A. M., \& Fontes, C. A. A. (2008). Avaliação nutricional da grama-estrela cv. Africana para vacas leiteiras em condições de pastejo. Revista Brasileira de Zootecnia, 37(2), 319-327. https://doi.org/10.1590/S1516-35982008000200019

Fontaneli, R. S., Fontaneli, R. S., Santos, H. P., Mariani, F., Pizotto A. C., Signor L. R., \& Zanella, D. (2012). Gramíneas Forrageiras Penenes de Verão. In R. S. Fontaneli, H. P. Santos, \& R. S. Fontaneli (Eds.), Forrageiras para integração lavoura-pecuária-floresta na Região Sul-Brasileira (2nd ed., pp. 247-284). Brasília-DF: Embrapa.

Janak, T. W., Baumann, P. A., Janak, S. E., \& Grichar, W. J.(2015). Use of selected herbicides and application methods for tolerance to Tifton 85 Bermudagrass [Cynodon dactylon (L.) Pers.]. American Journal of Experimental Agriculture, 8(5), 289-298. https://doi.org/10.9734/AJEA/2015/17727

MAPA (Ministério da Agricultura Pecuária e Abastecimento). (2018). Retrieved from http://agrofit.agricultura. gov.br/agrofit_cons/principal_agrofit_cons

Mislevy, P., Brown, W. F., Caro-Costas, R., Vicente-Chandler, J., Dunavin, L. S., Hall, D. W., ... Williams, N. J. (1989b). Florico stargrass (Circular 361, p. 15). Florida: University of Florida.

Mislevy, P., Brown, W. F., Dunavin, L. S., Hall, D. W., Kalmbacher, R. S., Overman, A. J., ... Williams, M. J. (1989a). Florona stargrass (Circular 362, p. 13). Florida: University of Florida.

Môro, F. V., \& Damião Filho, C. F. (1999). Alterações morfo-anatômicas das folhas de milho submetidas à aplicação de nicosulfuron. Planta Daninha, 17(3), 331-337. https://doi.org/10.1590/S0100-83581999000 300001

Pedreira, C. G. S. (2010). Gênero Cynodon. In D. M. Fonseca, \& J. A. Martuscello (Eds.), Plantas Forrageiras (pp.78-130). Viçosa: UFV.

Ribeiro Júnior, J. I. (2001). Análises estatísticas no SAEG (p. 301). Viçosa: Universidade Federal de Viçosa, Viçosa.

Santos, M. V., Ferreira, F. A., Freitas, F. C. L., Ikeda, A. K., Oliveira, F. L. R., Rocha, D. C. C., ... Assis, F. G. V. (2008). Tolerância do tifton 85 (Cynodon spp.) e da Brachiaria brizantha ao glyphosate. Planta Daninha, 26(2), 353-360. https://doi.org/10.1590/S0100-83582008000200011

Santos, M. V., Ferreira, F. A., Freitas, F. C. L., Tuffi Santos, L. D., Viana, J. M., Rocha, D. C. C., \& Fialho, C. M. T. (2007). Controle da Brachiaria brizantha, com o uso do glyphosate, na formação de pastagem de Tifton 85 (Cynodon spp.). Planta Daninha, 25(1), 149-155. https://doi.org/10.1590/S0100-83582007000100016 
Santos, M. V., Freitas, F. C. L., Ferreira, F. A., Carvalho, A. J., Braz, T. J. F., Cavali, J., \& Rodrigues, O. L. (2010). Tolerância do Tifton 85 ao glyphosate em diferentes épocas de aplicação. Planta Daninha, 28(1), 131-137. https://doi.org/10.1590/S0100-83582010000100016

SBCPD (Sociedade Brasileira da Ciência das Plantas Daninhas). (1995). Procedimentos para instalação e análise de experimentos com herbicidas (p. 42). SBCPD, Londrina, Brasil.

Seghese, M. A. (2009). Informações sobre gramíneas do gênero Cynodon (Comunicado Técnico, 1, p. 15). Maringá: CESUMAR.

Sollenberger, L. E. (2008). Sustainable production systems for Cynodon species in the Subtropics and Tropics. Revista Brasileira de Zootecnia, 37, 85-100. https://doi.org/10.1590/S1516-35982008001300011

Vendramini, J., \& Mislevy, P. (2016). Stargrass. In J. Vendramini (Eds.), Florida forage handbook. University of Florida/IFAS Extension (SS-AGR-62), Florida, Estados Unidos.

\section{Copyrights}

Copyright for this article is retained by the author(s), with first publication rights granted to the journal.

This is an open-access article distributed under the terms and conditions of the Creative Commons Attribution license (http://creativecommons.org/licenses/by/4.0/). 